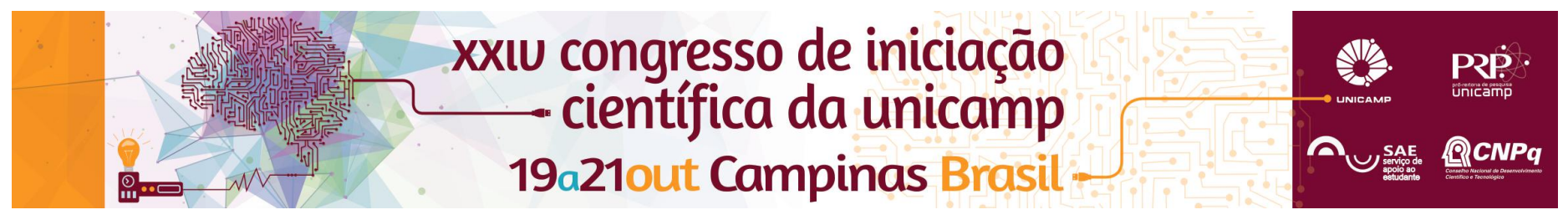

\title{
Um diálogo entre Arquitetura, pedagogia e design: Estudo de um artefato.
}

\section{Isabella Rebolla Bueno*.}

\begin{abstract}
Resumo
A pesquisa centra-se no estudo da ergonomia infantil e em como esta atua em comunicação com a pedagogia toscana e seus métodos. Os principais pontos de intersecção do diálogo entre a ergonomia infantil e a pedagogia toscana além da arquitetura - são os mobiliários que corroboram para a interação da criança com o meio - e também estimulam o convívio desta com os adultos. A partir de uma breve contextualização sobre a metodologia pedagógica da região da Toscana e Reggio Emília, e suas filosofias, será possível compreender o diálogo que os mobiliários desenvolvidos pelo designer pedagogo Aldo Fortunati proporcionam. E como estes artefatos se apresentam perante as crianças que os utilizam.
\end{abstract}

\section{Palavras-chave:}

Arquitetura, Pedagogia, Design de Mobiliários.

\section{Introdução}

O cenário educacional é o fator constante presente durante o crescimento da criança e interfere significativamente no seu progresso.

Se considerarmos o desenvolvimento pessoal e social de uma criança como propósito maior da educação, há de levantarmos como questão presente o meio em que esta se desenvolve. O meio físico se incluí nesta questão, ele expressa muito das intenções dos seus usuários mais influentes - os educadores - para com os seus usuários mais preponderantes - as crianças.

Muito da consideração do espaço (meio físico) pelos seus usuários reside na escala em que este se apresenta incluindo os mobiliários que o caracteriza. E ao pensar no mobiliário escolar é importante considera-lo em sua maioria destinado às crianças, e não aos adultos.

Assim, o design da mobília destinada as crianças e sua escala própria é importante: os mobiliários para usuários infantis não podem ser considerados apenas a redução daqueles destinados aos adultos - estes devem nascer como complementação de um processo global de projeto, arquitetônico ou educacional.

Levando esta linha de raciocínio, a Pedagogia da Região da Reggio Emilia e Toscana, na Itália, apresenta uma porção de conceitos que levam o respeito pelas proporções dos pequenos a outro patamar. Os ambientes de suas escolas e creches refletem o empenho em desenvolver as crianças como cidadãs autoconscientes e socialmente responsáveis - iniciando este processo na primeira infância.

Como processo paralelo ao crescimento e popularização, na Itália, do que podemos e iremos chamar de "Pedagogia Toscana", encontra-se o caminhar de designs de interiores voltados à complementar esta fase de desenvolvimento infantil. Principal para este estudo são linhas de mobiliários criadas por Aldo Fortunati, pedagogo de renome e designer de mobílias focadas na primeira infância.

Aldo Fortunati em sua carreira como pedagogo, levantava a importância com o desenvolvimento das crianças nos ambientes educacionais. Os mesmos não ofereciam (pelo menos não conscientemente) o amparo que as crianças necessitam para desenvolvimento da criatividade e autoconsciência: fatores necessários para a formação de carácter e personalidade na infância. Havia na Itália diversas linhas teóricas de referência que não apenas complementavam a pedagogia "Toscana", mas exemplificavam como que a mesma deveria ser levada a diante em seus ambientes, mobiliários, experiências que deveriam proporcionar etc. Assim, o outro lado de Aldo, como designer de mobiliário, procurava maximizar o processo de desenvolvimento da criança através do que estas linhas exemplificavam como necessárias, no ambiente e nas mobílias, para a experiência das crianças.

Assim como o entendimento da "pedagogia Toscana" está atrelado ao um histórico sócio-político italiano do surgimento e propostas de creches públicas; o entendimento da importância e papel dos mobiliários de Aldo Fortunati está atrelado ao conhecimento das diversas linhas de referência, as quais projetam nos ambientes internos das escolas o que eles devem proporcionar, e do papel de Aldo como atuante na concretização destas projeções.

\section{Resultados e Discussão}

Este presente estudo pretende apresentar um vislumbre histórico das etapas que trouxeram Aldo ao papel que ele se encontra hoje como designer, além de pedagogo. Revelando brevemente do que se trata esta "concretização" nos mobiliários de Aldo e como estes artefatos assumem sua importância no cenário delicado e fundamental da infância.

Complementarmente a este objetivo geral encontra-se a representação técnica dos artefatos escolhidos para estudo e a demonstração dos mesmos em um cenário de escala da criança.

\section{Conclusões}

A importância deste estudo consiste em apresentar um panorama geral de um conceito italiano de educação que cria esta interface entre o ambiente, o usuário e o propósito. E onde a arquitetura porta-se como um pilar que transcende o da infraestrutura, portando-se com seu propósito além de sua função. 